\title{
UPOREDNA ANALIZA STRATEGIJA NACIONALNE BEZBEDNOSTI REPUBLIKE SRBIJE I REPUBLIKE HRVATSKE
}

\author{
Radovan Miladinović, Hatidža Beriša** \\ Univerzitet odbrane u Beogradu, Škola nacionalne odbrane
}

I radu se uporedno analiziraju strategije nacionalne bezbednosti Republike Srbije i Republike Hrvatske sa pokušajem sveobuhvatne identifikacije ključnih pokazatelja i stavova ove dve zemlje u pogledu doživljaja vlastite nacionalne bezbednosti i načina da je sačuvaju i unaprede.

Ključne reči: bezbednost, bezbednosno okruženje, vrednosti, strategija, nacionalna bezbednost, interesi

\section{Uvod}

edna od karakteristika savremenih društvenih okolnosti je svakako dinamičan raz-

voj nacija i modernih država, pri čemu ih postojanje jasne vizije ili strategije planiranog razvitka lišava problema u sopstvenoj orijentaciji i definisanju vlastitog progresa. Značajan pokazatelj razvijenih i uređenih država svakako je postojanje strategije nacionalne bezbednosti, kao dokumenta koji jasno ukazuje viziju i očekivanja jedne zemlje u višegodišnjoj budućnosti. Može se reći da bez temeljno uređene bezbednosti na nacionalnom nivou, ne može se na poželjan način ostvariti bezbednost kako na regionalnom ili globalnom nivou, tako i na nižim sferama bezbednosti kakve su lična, grupna socijetalna, korporativna i druge.

Događaji širom sveta, često i u sopstvenom okruženju gotovo da iznuđuju od samih država da imaju spremne odgovore na krizne situacije, kakve su borba protiv terorizma, problemi sa migrantima, tehničko-tehnološki akcidenti i sl. U takvim okolnostima ugla države je krucijalna i jednostavno nezaobilazna. Strategija nacionalne bezbednosti predstavlja upravo takav dokument kojim se koncizno definišu pitanja od značaja za bezbednost na prostoru jedne države.

Kraj prošlog i početak ovog veka, uporedo sa beskrupuloznom borbom za nova tržišta i profit, doneo je i ekspanziju destruktivnih pojava i procesa sa neslućenom snagom i efektima. Sve više se pojavljuju novi oblici ugrožavanja bezbednosti, bez obzira da li je posmatrali kao ličnu, nacionalnu ili državnu. Pored klasičnog poimanja neprijatelja, sfera bezbednosti suočava se i sa tzv. netradicionalnim izazovima, rizicima i pretnjama koje karakteriše asimetričnost, nepredvidivost i transnacionalni karakter. Raspad SFRJ je, po-

\footnotetext{
* Rad je nastao tokom školovanja na Generalštabnom usavršavanju 2019. godine.

** Priređivač rada i nastavnik u Katedri strategije.
} 
red svih nemilih događaja i razaranja, svim novoformiranim državama doneo jednu potpuno novu sferu u njihovom postojanju. Bilo je potreban dug niz godina kako bi svaka za sebe, vođene interesima i željama, izradile sopstvene vizije i strategije za budućnost, iz ugla sopstvene nacionalne bezbednosti.

Istraživanje je realizovano kroz tri dela. U prvom delu navedena su kratka pojmovna određenja o osnovama strategije nacionalne bezbednosti. Drugi segment istraživanja odnosi se na proučavanje Strategije nacionalne bezbednosti Republike Srbije iz 2009. godine, a potom i proučavanje prethodne Strategije nacionalne bezbednosti Republike Hrvatske, iz 2002. godine, kao i trenutno važeće Strategije iz 2017. godine. Treći deo predstavlja analizu njihovih najvažnijih utemeljenja i dat pokušaj uviđanja njihovih sličnosti i razlika. U zaključku je napravljena sinteza opisivanog, ekspliciranog i problemski razjašnjenog sadržaja.

\section{Osnove strategije nacionalne bezbednosti}

Bezbednost jednog društva i bezbednost države zajedno čine deo nacionalne bezbednosti, kojom jedna zemlja učestvuje u međunarodnoj i globalnoj bezbednosti. Za shvatanje nacionalne bezbednosti može se reći da u užem smislu, ona predstavlja „stanje zaštićenog, slobodnog, stabilnog i izvesnog postojanja, funkcionisanja i razvoja jedne države (zemlje), odnosno stanje u kojem nema ozbiljnih pretnji i opasnosti za opstanak jedne države, za njenu nezavisnost, teritorijalnu celokupnost i ustavno-pravni poredak, kao i za život, prava i slobode njenih građana i zdravu životnu sredinu (stanje neugroženosti i bezopasnosti)“. ${ }^{1}$ To stanje zaštićenosti vitalnih vrednosti i interesa, kome sve države teže, izgrađuje se svim kapacitetima (vojnim, civilnim, državnim i dr.), uz izvesno oslanjanje na različite vidove međunarodne saradnje u bezbednosti i brojne međunarodne aktere. Ugrožavajuće pojave današnjice, poput kriminala, terorizma, unutrašnjih oružanih sukoba, ekoloških i socijalnih pretnji, prirodnih i tehničko-tehnoloških pretnji same po sebi su uzrokovale jačanje prevencije odnosno mere smanjivanja opasnosti, kao značajne sfere zaštitne funkcije. Ove pojave u većoj meri su zastupljene u odnosu na „klasične", poput oružane agresije, političkih i vojnih pritisaka i sl. ${ }^{2}$

Imajući u vidu predmet ovog rada Republike Srbije, za pojmovno određenje strategije nacionalne bezbednosti uzeto je da se radi o „skupu iskaza u formi pravila, principa i normi, koji se koriste u donošenju dugoročnih upravljačkih akcija u sistemu odbrane i bezbednosti države“. ${ }^{3}$ lako se na prvi pogled čini da joj sintaksa određuje karakter, ona zapravo ima svoj uzvišeni cilj - zaštita najviših nacionalnih vrednosti kroz ostvarivanje nacionalnih interesa ${ }^{4}$. Ovaj pojam u upotrebi je u većini onih država koje su izvršile transformaciju svog sistema bezbednosti, i bez obzira na svoj evolutivni razvoj, ona suštinski predstavlja društvenu viziju i dugoročno projektovanje. Željeni rezultat svake strategije nacionalne bezbednosti može se generalizovati na dostizanje i očuvanje određenih vrednosti, interesa i ciljeva, bez obzira na oblast društvenog života.

\footnotetext{
${ }^{1}$ Mijalković V. S., Nacionalna bezbednost, Beograd, 2015, str. 83.

${ }^{2}$ Isto, str. 81.

${ }^{3}$ Kovač M., Strategijsko planiranje odbrane, Beograd, 2009, str. 232.

${ }^{4}$ Isto.
} 
Da se zaista radi o najvišem i najvažnijem strateškom dokumentu govori i činjenica da u sferi najviše državne politike bezbednosti i odbrane, Strategija nacionalne bezbednosti predstavlja polazište za definisanje Strategije odbrane, Strategijskog pregleda odbrane i Bele knjige odbrane, dok je u oblasti vojne delatnosti ona osnov za vojnu strategiju i sva doktrinarna dokumenta. Gledano šire, i strategija spoljne politike, ekonomskog razvoja, unutrašnje bezbednosti, socijalnog razvoja i druge strategije potiču iz strategije nacionalne bezbednosti, pri čemu svaka od njih tretira probleme nacionalne bezbednosti sa svog aspekta i daje odgovore na njih. U narednom poglavlju analiziran je sadržaj strategija nacionalnih bezbednosti Republike Srbije i Republike Hrvatske.

\section{Analiza strategija nacionalne bezbednosti Hrvatske i Srbije}

Zemlje jugoistočne Evrope su bile u znatno složenijim uslovima nego ostale države članice Varšavskog ugovora, jer su pored aktuelnih procesa globalizacije i tranzicije bile opterećene i konfliktima devedesetih godina na teritoriji bivše SFRJ. Danas je situacija bitno drugačija i ovaj region nije više "crna rupa" evropske bezbednosti. Mogućnost bilo kakvog međudržavnog sukoba na lokalnom ili regionalnom nivou je skoro eliminisana. Svojevrstan paradoks predstavlja i činjenica da nisu eliminisane opasnosti koje mogu ugroziti mir u ovom regionu i pored prisustva međunarodnih snaga u $\mathrm{BiH}$ i na Kosovu i Metohiji. Nacionalistička osećanja, etnički sukobi, ksenofobija i ekonomski problemi su još uvek deo političke realnosti. Takođe treba napomenuti organizovani kriminal, korupciju i sivu ekonomiju koje su karakteristične za sve države na ovim prostorima. Sve države jugoistočne Evrope su izrazile svoja stremljenja za članstvom u Evropsku uniju i NATO, osim Republike Srbije, koja je proglasila vojnu neutralnost i stremi samo članstvu u EU.

U takvoj situaciji sve zemlje na ovim prostorima su izvršile detaljnu analizu bezbednosnog okruženja, prepoznale izazove, rizike i pretnje sopstvenoj bezbednosti i definisale osnovne nacionalne vrednosti, interese i ciljeve. Na osnovu sveobuhvatnih procena izradile su Strategije nacionalne bezbednosti (ili dokumente sličnog sadržaja) u kojima su dati osnovni državni stavovi u odnosu na navedena pitanja.

Težište ovog poglavlja biće na analizi nacionalnih strategija bezbednosti zemalja u okruženju. Razmotriće se neophodne pretpostavke koje će na kraju biti predmet komparativne analize.

\section{Strategija nacionalne bezbednosti Republike Srbije}

Strategijom nacionalne bezbednosti Republike Srbije, kao najvišim strateškim dokumentom, deklarativno se štite njeni nacionalni interesi. Ona utvrđuje osnove politike bezbednosti u zaštiti nacionalnih interesa od potencijalnih izazova, rizika i pretnji u različitim sferama društvenog života, strukturu, načela funkcionisanja i odgovornosti u sistemu bezbednosti. Njeni delovi bi se, u osnovi, mogli grupisati u tri celine: prva, koja se odnosi na ugrožavanje bezbednosti (bezbednosno okruženje, izazovi, rizici i pretnje), druga, koja obuhvata interese u oblasti nacionalne bezbednosti (vrednosti, interesi i ciljevi), i treća, gde se govori o reagovanju države radi očuvanja nacionalne bezbednosti (politika nacionalne bezbednosti, sistem nacionalne bezbednosti sa resursima za ostvarivanje interesa nacionalne bezbednosti). 
Svakoj odgovornoj zemlji, njenim političkim strukturama koje se bave spoljnom i bezbednosnom politikom, u centru pažnje treba da je njeno sopstveno bezbednosno okruženje. Aktivnosti na praćenju tog okruženja se ne završavaju donošenjem strategije nacionalne bezbednosti, usvajanjem neke procene, već predstavljaju neprekidnu aktivnost. Kada je u pitanju Strategija nacionalne bezbednosti naše države, bezbednosno okruženje sadrži globalno okruženje, regionalno okruženje i bezbednost Republike Srbije. ${ }^{5}$

Analizirajući globalno okruženje, ističe se da je mogućnost izbijanja vojnog sukoba širokih razmera značajno manja nakon završetka Hladnog rata, ali postoje kako tradicionalni, tako i novi izazovi rizici i pretnje. ${ }^{6}$ Razmatrajući in, zaključuje se da globalnu bezbednost, sa vojnog aspekta, u najvećoj meri narušavaju regionalni i lokalni sukobi, terorizam i proliferacija oružja za masovno uništenje. Etnički i verski ekstremizam, organizovani kriminal i ilegalne migracije, sami po sebi, nemaju vojni karakter, ali posledice njihovog širenja i jačanja mogu poprimiti i ovu dimenziju. Sa druge strane, porast siromaštva i socijalne ugroženosti, kao i klimatske promene i sve izraženiji deficit energetskih resursa se mogu svrstati u nevojne izazove, rizike i pretnje. Zajedničko za sve njih je da su teško predvidivi, asimetrični i transnacionalni, tako da nijedna država zasebno nema kapacitete da ih sama reši. U takvim okolnostima, sagledavanje bezbednosti zahteva širi pristup i sliku, gde je nacionalna bezbednost u direktnoj sprezi sa bezbednošću bližeg i daljeg okruženja.

Vreme izrade Strategije nacionalne bezbednosti Republike Srbije (2009. godina), na regionalnom planu, u najvećoj meri odslikavali su napori država u okruženju da jačaju svoje demokratske kapacitete, unapređuju saradnju i međusobni dijalog, sa vizijom ulaska u Evropsku uniju i NATO. Međutim, i pored ovih afirmativnih pokazatelja, određene pojave negativno utiču na bezbednosnu situaciju i opterećuju međusobne odnose zemalja regiona. I na ovom nivou ugrožavanja bezbednosti, definisani izazovi, rizici i pretnje mogu da se podele na osnovu prirode posledica koje mogu izazvati. U grupu onih koji su vojnog karaktera gotovo apriorno se mogu svrstati separatističke težnje u regionu i terorizam, ekspanzija organizovanog kriminala, korupcija, nedozvoljena trgovina narkoticima, oružjem i ljudima, koji su prisutni na Kosovu i Metohiji (KiM) a prelivaju se i narušavaju bezbednost susednih država. Kada su aspiracije pojedinih etničkih grupa za otcepljenjem u pitanju, onda je među njima najneposredniji pokušaj otcepljenja dela teritorije Republike Srbije jednostranim proglašenjem nezavisnosti KiM. ${ }^{8}$ Međutim, nikako se ne može izbeći postojanje „vojnog“ u prirodi priznavanja tzv. „Republike Kosovo“ od strane pojedinih država u regionu, izraženom verskom, nacionalnom i političkom ekstremizmu i pokušaju revizije Dejtonskog sporazuma i daljem egzistiranju nasleđenih problema i protivrečnosti iz prošlosti. Nevojni karakter ima kompleksan i velikim silama uvek „interesantan“ položaj Jugoistočne Evrope, nerešena pitanja povratka izbeglica sa problemima vlasništva imovine, te postojanje izvesnih problema kao posledice neodgovarajuće integrisanosti manjinskih zajednica i grupa u šire društveno okruženje. Poput većine država Jugoistočne Evrope, i Srbija je prepoznala potrebu za zajedničke napore u izgradnji „zajedničkih mehanizama za prevenciju rizika i pretnji i za upravljanje kriznim situacijama“, što i Evropska unija prepoznaje kao jedan od uslova za približavanje i priključenje ovoj organizaciji. ${ }^{9}$

\footnotetext{
${ }^{5}$ Strategija NB R. Srbije, Beograd, 2009, str. 5.

${ }^{6}$ Isto, str. 4.

${ }^{7}$ Isto.

${ }^{8}$ Strategija NB R. Srbije, Beograd, 2009, str. 6.

${ }^{9}$ Isto.
} 
Pored globalnog i regionalnog aspekta sagledavanja ugrožavanja bezbednosti Republike Srbije, uticaj činilaca na bezbednost unutar države se gotovo svakodnevno može pratiti i procenjivati. Značajan deo tih činilaca koji su prepoznati Strategijom nacionalne bezbednosti naše države, u najvećoj meri prožima problem KiM multispektralno, obzirom da na tom delu svoje teritorije država ne ostvaruje neposredan uticaj i kontrolu. Sagledavanje prepoznatih izazova, rizika i pretnji se takođe može izvršiti sa vojnog, odnosno nevojnog aspekta. lako se nijedna mogućnost ugrožavanja bezbednosti neke zemlje ne sme smatrati da je od drugorazrednog značaja, u nastavku će prvo biti analizirani opasnosti koje imaju vojni karakter.

Bezbednosna situacija na teritoriji Autonomne pokrajine Kosovo i Metohija, koja je nastala uspostavljanjem međunarodne misije i nelegalnim samoproklamovanjem „Republike Kosovo", predstavlja dominantni izvor nestabilnosti Republike Srbije. Društveni život u tom delu zemlje karakterišu: „strah i opšta nesigurnost uzrokovani etnički motivisanim nasiljem nad pripadnicima srpskog naroda i manjinskih etničkih zajednica, spora izgradnja demokratskih institucija i demokratske političke kulture i odnosa, nepoštovanje osnovnih ljudskih prava, uskraćivanje slobode kretanja, ekspanzija organizovanog kriminala (prvenstveno narko-kriminala, trgovine oružjem i ljudima, ilegalnih migracija), uzurpacija i uništavanje privatne imovine i kulturno-istorijskog nasleđa i otežan proces povratka prognanih i interno raseljenih lica“. ${ }^{10}$ Upitni rezultati međunarodnog civilnog i vojnog prisustva u južnoj pokrajini povod su daljeg jačanja negativnog uticaja na bezbednost Republike Srbije, sa neznatnom mogućnošću predviđanja njenog daljeg razvoja. Pored navedene pretnje, na ukupno bezbednosno stanje u državi značajan uticaj imaju i posledice građanskog rata na prostorima bivše SFRJ, posledice bombardovanja SRJ, terorizam, organizovani kriminal i destruktivno delovanje pojedinih verskih sekti. Opasnost po bezbednost Republike Srbije, koje mogu imati prefiks „nevojni“, svakako predstavljaju izraženi problemi tranzicije, organizovani kriminal, korupcija, nelegalna trgovina ljudima, oružjem i narkoticima, delovanje verskih sekti i dr. Značajno je naglasiti da su navedene „nevojne“ pretnje karakteristične za gotovo sve zemlje regiona.

Strategijom nacionalne bezbednosti Republike Srbije, kao najizraženiji bezbednosni izazovi, rizici i pretnje su navedeni sledeći: terorizam, oružana pobuna, sporovi uz upotrebu oružja, separatizam, razni oblici organizovanog kriminala, etnička i verska netolerancija i ekstremizam, obaveštajne delatnosti drugih država, proliferacija oružja za masovno uništenje, korupcija, problemi ekonomskog razvoja, energetska nebezbednost, neravnomeran privredni i demografski razvoj, nerešen status i težak položaj izbeglih, prognanih i interno raseljenih lica, nedovršen proces razgraničenja između država nekadašnje SFRJ, nekontrolisano trošenje prirodnih resursa i ugrožavanje životne sredine, posledice elementarnih nepogoda i tehničkih i tehnoloških nesreća, kao i ugrožavanje životne sredine i zdravlja građana, opasnosti povezane sa pojavljivanjem i širenjem infektivnih bolesti kod ljudi i zaraza kod životinja, narkomanija, destruktivno delovanje pojedinih verskih sekti i kultova, visokotehnološki kriminal i ugrožavanje informacionih i telekomunikacionih sistema i promena klime. Pored navedenog, potrebno je naglasiti da je „s manjom ili većom verovatnoćom ispoljavanja i prepoznavanja, moguća i zloupotreba novih tehnologija i naučnih dostignuća u oblasti informatike, genetskog inženjeringa, medicine,

\footnotetext{
${ }^{10}$ Mijalković V. S., Nacionalna bezbednost, Beograd, 2015, str. 98.
} 
meteorologije i drugih naučnih oblasti“. ${ }^{11}$ Pozivajući se na rad Janković D. „Reforma obaveštajno-bezbednosnog sistema" iz 2007. godine, isti izvor navodi da su među deset dominantnih bezbednosnih problema, oružana pobuna, terorizam, etničke napetosti, nacionalni i verski ekstremizam, organizovani kriminal i prirodne i industrijske kata strofe i epidemije većih razmera, sa najvećim stepenom intenziteta, posebno uzimajući ih kratkoročno. ${ }^{12}$ Svakako najveća pretnja bezbednosti Republike Srbije jeste protivpravno jednostrano proglašena nezavisnost Kosova i Metohije.

Bezbednost države i stanovništva, odnosno nacionalna bezbednost, može biti ugrožena uticajem vojnih rizika i pretnji. Tu se pre svega misli na masovnu upotrebu konvencionalnog naoružanja, pa i oružja za masovno uništavanje. Takve pojave ugrožavanja bezbednosti su, u prvom redu, opasnost od oružane agresije, oružana intervencija i oružani pritisci, i oružana pobuna i građanski rat koji se odvijaju unutar zemlje. Međutim, šire gledano, svoju vojnu dimenziju svakako mogu imati terorizam, proliferacija oružja za masovno uništenje i nacionalni i verski ekstremizam. Ovako posmatrano, navedeni rizici i pretnje se ubrajaju u ugrožavajuće pojave ljudskog porekla koje se nazivaju još i oružanim (spoljnim i unutrašnjim) oblicima ugrožavanja nacionalne bezbednosti.

Kako je navedeno u Strategiji nacionalne bezbednosti, "interesi Republike Srbije izraz su vitalnih vrednosti i potreba građana, naroda i države", ${ }^{13}$ zbog čega ih i određuje njen najviši pravni akt, Ustav. Nezavisnost, suverenitet, teritorijalni integritet, sloboda, jednakost, izgradnja i očuvanje mira, vladavina prava, demokratija, socijalna pravda, ljudska prava i slobode, nacionalna, rasna, verska ravnopravnost i ravnopravnost polova, nepovredivost imovine i očuvanje životne sredine, ${ }^{14}$ predstavljaju nacionalne vrednosti Republike Srbije. One se, kao krovne vrednosti, štite ostvarivanjem nacionalnih interesa, koji obuhvataju sve oblasti društvenog života i u skladu su sa demokratskim tekovinama i standardima savremenog društva.

Kao i kod svih država regiona, ishodište nacionalnih interesa su nacionalne vrednosti definisane Ustavom Republike Srbije. Osnovnim nacionalnim vrednostima se smatraju: nezavisnost, suverenitet, teritorijalni integritet, sloboda, jednakost, izgradnja i očuvanje mira, vladavina prava, demokratija, socijalna pravda, ljudska prava i slobode, nacionalna, rasna, verska ravnopravnost i ravnopravnost polova, nepovredivost imovine i očuvanje životne sredine ${ }^{15}$. Nacionalne vrednosti se štite ostvarivanjem nacionalnih interesa, a zaštita nacionalnih interesa je smisao postojanja sistema nacionalne bezbednosti.

Nacionalni interesi obuhvataju sve oblasti društvenog života i u skladu su sa demokratskim tekovinama i standardima savremenog društva. Nacionalni interesi Republike Srbije u oblasti bezbednosti su:

- očuvanje suverenosti, nezavisnosti i teritorijalne celovitosti Republike Srbije i nacionalnog, kulturnog, verskog i istorijskog identiteta srpskog naroda i nacionalnih manjina;

- očuvanje unutrašnje stabilnosti, vladavine prava, razvoj demokratije i demokratskih institucija i integracija u Evropsku uniju i druge međunarodne strukture;

\footnotetext{
${ }^{11}$ Mijalković V. S., Nacionalna bezbednost, Beograd, 2015, str. 99.

${ }^{12}$ Isto. Vidi šire na str. 100.

${ }^{13}$ Strategija NB R. Srbije, Beograd, 2009, str. 10.

${ }^{14}$ Isto, str. 13.

${ }^{15}$ Strategija NB R. Srbije, Beograd, 2009, str. 13.
} 
- zaštita života i imovine građana Republike Srbije;

- ekonomski razvoj, uz očuvanje životne sredine i prirodnih resursa;

- stvaranje mirnog, stabilnog i sigurnog bezbednosnog okruženja;

- očuvanje i razvoj međunarodnog poretka utemeljenog na principima pravde, poštovanja međunarodnog prava i političke i državne ravnopravnosti;

- stalno održavanje i unapređivanje veza sa Srbima koji žive i rade u inostranstvu.

Konstatuje se da je trajno opredeljenje Republike Srbije da svoje nacionalne interese ostvaruje uz uvažavanje interesa drugih država u regionu i svetu. Istaknuta je odlučnost upotrebe svih raspoloživih resursa u zaštiti sopstvenih nacionalnih interesa.

Važeća Strategija nacionalne bezbednosti Republike Srbije usvojena je 2009. godine. Od momenta donošenja, u svim sferama njenog bezbednosnog okruženja dogodile su se značajne promene. Zbog toga Republika Srbija, kao i ostale savremene države, mora da prati takve promene, a svoju bezbednosnu politiku prilagođava tim promenama. Time se ulažu napori da se na najbolji način štite nacionalne vrednosti i interesi. Proces izrade nove strategije, koji je u svojoj poodmakloj fazi, izvesno je da će dati aktuelni presek bezbednosne situacije i procenu bezbednosnih rizika. Trenutno stanje odslikava jasan stav da Republika Srbija neće priznati jednostrano proglašenu nezavisnost Kosova i Metohije, ali će u interesu regionalne stabilnosti i što boljih srpsko-albanskih odnosa nastaviti dijalog sa privremenim institucijama u Prištini uz posredovanje EU, do postizanja održivog i obostrano prihvatljivog dogovora. U skladu sa svojim opredeljenjem, kao vojno neutralna zemlja, ona će nastaviti saradnju sa NATO i ODKB (Organizacijom Dogovora o Kolektivnoj Bezbednosti). Takođe, čvrsto je opredeljena da u okviru procesa pristupanja doprinosi zajedničkoj spoljnoj, bezbednosnoj i odbrambenoj politici Evropske unije, te da se integriše u koncepte te evropske politike. U cilju ubrzanja svog i napredovanja ostalih zemalja u regionu ka članstvu u Evropskoj uniji, Srbija će nastaviti aktivno da učestvuje u nizu regionalnih inicijativa koje doprinose tom procesu.

lako prethodno navedeni stavovi odslikavaju trenutne društvene okolnosti na nacionalnom nivou, protekle dve decenije pokazale su da uvek mogu da se pojave novi, nepredviđeni bezbednosni izazovi, rizici i pretnje. Zato u periodu kada treba da se definišu i donesu nova strateška dokumenta, bez obzira na izražavanje krajnje načelnih stavova u njima, treba imati na umu da će, kao takva, biti podložna proveri u svakodnevnom životu i eventualnim korekcijama.

\section{Strategija nacionalne bezbednosti Republike Hrvatske}

Republika Hrvatska postala je samostalna država nakon izvršene secesije i građanskog rata u procesu raspada bivše SFR Jugoslavije ${ }^{16}$. Istovremeno kad i Slovenija, njena nezavisnost je priznata u OUN u decembru 1991. godine, ${ }^{17}$ bez obzira na činjenicu što su na njenoj teritoriji, kao i u Bosni i Hercegovini ratna dešavanja trajala do 1995. godine.

\footnotetext{
${ }^{16}$ https://www.tportal.hr/vijesti/clanak/zasto-bas-danas-slavimo-hrvatsku-neovisnost-foto-20171005 (poslednji pristup 10.01.2018.)

${ }^{17}$ https://www.dalmacijadanas.hr/26-godina-od-priznanja-rh-znate-li-koja-je-zemlja-prva-priznala-hrvatku (poslenji pristup10.01.2018.)
} 
Gotovo od samog čina proglašenja nezavisnosti i priznavanja u UN, a posebno nakon prestanka ratnih dejstava u bivšoj SFRJ, Hrvatska se orijentisala ka evroatlanskim integracijama. Tako usmeravajući svoju unutrašnju i spoljnu politiku, 2009. godine ova zemlja je primljena u Severnoatlantski Savez (NATO), ${ }^{18}$ dok je članica Evropske unije (EU) postala 2013. godine. ${ }^{19}$ Izvršenom analizom, za ovaj dokument se može reći da je u najvećoj meri bio orijentisan ka putu Hrvatske u NATO i EU.

Po uzoru na većinu razvijenih zapadnih zemalja koje su normativno-pravno definisale svoje nacionalne strategije, Hrvatski sabor je svoju prvu Strategiju nacionalne sigurnosti doneo 19. marta 2002. godine, kao koncepcijski dokument u kojem se iznose osnovni politički stavovi o nacionalnoj bezbednosti. Ta strategija je u najvećoj meri bila orijentisana ka putu Hrvatske u NATO. Nakon prijema u NATO, duži niz godina trajali su pokušaji da se usvoji nova strategija, tako da je 2010. godine izrađen i nacrt nove strategije koji nije usvojen. Nešto kasnije, nakon izvršenih formalnih i proceduralnih postupaka, 14. jula 2017. godine Hrvatski sabor je usvojio novu Strategiju nacionalne bezbednosti. ${ }^{20} \mathrm{Da}$ bi se uočile evidentne promene koje postoje između navedenih dokumenata, u narednom delu rada biće izvršena njihova međusobna analiza.

Strategija iz 2002. godine sadržala je šest poglavlja, koja su se odnosila na bezbednosno okruženje i izazove Republike Hrvatske, njene vrednosti i interese, identifikovane izazove, rizike i pretnje, bezbednosni koncept, bezbednosnu politiku Republike Hrvatske sa svojim područjima i instrumentima i prigodan zaključak. ${ }^{21} U$ navođenju njenog sadržaja, kao područja bezbednosne politike, isticala se integracija u NATO, odnosno integracija u EU i Evropske bezbednosne organizacije, uz odnose sa susedima, saradnju sa međunarodnim integracijama i regionalnu saradnju, kontrolu oružja i mere izgradnje poverenja i bezbednosti, doprinos mirovnim i humanitarnim organizacijama, razvoj odbrambenih sposobnosti i unutrašnje bezbednosti države. ${ }^{22}$

Sa druge strane, u strukturi Strategije iz 2017. godine ima pet poglavlja. ${ }^{23}$ Uvodni deo proširen je iskazom vizije i opisom bezbednosnog koncepta, nakon čega su navedeni nacionalni interesi. Analiza bezbednosnog okruženja izvršena je višedimenzionalno, na globalnom nivou, nivou Evrope i evropskog susedstva, odnosno jugoistočnog susedstva, da bi se potom navele bezbednosne pretnje, rizici i izazovi za Republiku Hrvatsku. Ovde je bitno uočiti da se u delu koji se odnosi na bezbednosnu politiku, iako se ona eksplicitno tako ne naziva, svakako uočavaju noviji trendovi definisanja strateških ciljeva, instrumenata i mehanizama za njihovo ostvarivanje. Tako su navedeni: a) bezbednost stanovništva, teritorijalni integritet i suverenitet; b) dobrobit i prosperitet građana; v) nacionalni identitet, međunarodni ugled i uticaj Republike Hrvatske i g) Hrvati izvan Hrvatske. ${ }^{24}$

\footnotetext{
${ }^{18}$ http://www.mvep.hr/hr/vanjska-politika/multilateralni-odnosio/multi-org-inicijative/nato/hrvatska-i-nato/ (poslednji pristup 10.01.2018.)

${ }^{19} \mathrm{https} / / /$ vlada.gov.hr/proslava-pristupanja-hrvatske-u-europsku-uniju/1155 (poslednji pristup 10.01.2018.)

${ }^{20}$ Strategija NB R. Hrvatske, Zagreb, 2017, str. 1.

${ }^{21}$ Strategija NB R. Hrvatske, Zagreb, 2002, str. 1.

${ }^{22}$ Isto, str. 8.

${ }^{23}$ Strategija NB R. Hrvatske, Zagreb, 2017, str. 1.

${ }^{24}$ Strategija NB R. Hrvatske, Zagreb, 2017, str. 6.
} 
Obzirom da je između objavljivanja strategija prošlo 15 godina, sama po sebi se nameće potreba upoređivanja nekih od njihovih posebnih sadržaja, poput izazova, rizika i pretnji bezbednosti, nacionalnih interesa i ciljeva, kao i mehanizama ostvarivanja bezbednosti. Konstatacija u samom uvodu da su „članstvom u Organizaciji Severnoatlantskog ugovora i Evropskoj uniji ostvareni važni spoljnopolitički i bezbednosni ciljevi i stvoreni uslovi koji Republici Hrvatskoj omogućuju dodatne privredne, političke i bezbednosne razvojne prilike" ukazuje na okvir, drugačije sagledavanje i dimenzionisanje stvarnosti, pojava i procesa koji u njoj postoje. Sa stanovišta bezbednosnog koncepta, Strategija iz 2017. godine uvela je nova paradigmu bezbednosti, koja se zapravo koncipira „na modelu ljudske bezbednosti, odnosno bezbednosti pojedinca - svakog građanina Republike Hrvatske“. ${ }^{25}$

Pristup u analizi bezbednosnog okruženja i izazova značajno se izmenio. Od prvobitne, gotovo nasumične i nesistematične analize kojom su se eksplicitno navodile i države - izvori nestabilnosti za Republiku Hrvatsku, ${ }^{26}$ Strategijom iz 2017. godine učinjen je značajan kvalitativni pomak. Ovim dokumentom izvršena je analiza na globalnom nivou, zatim u kontekstu Evrope i evropskog susedstva, da bi poseban odeljak bio o „Jugoistočnom susedstvu" gde se ni jednom rečju direktno ne pominje Republika Srbija, ali se iz „ostrašćenog“ i „zavereničkog“ opisivanja, takvo nešto može lako zaključiti.

Strategijom iz 2002. godine bilo je prepoznato 15 izazova, rizika i pretnji, od kojih su tri vojnog karaktera - opasnost od vojne pretnje, transnacionalne pretnje koje se prelivaju na evropski kontinent i sukobi na tranzitnim pravcima i oko resursa ${ }^{27}$. Izradom nove Strategije iz 2017. godine, uvažavajući činjenicu o dinamičnosti društvenih dešavanja i promena u svetu i u vlastitoj državi, Hrvatska je, u odnosu na prethodnu, u novoj Strategiji prepoznala svega šest izazova, rizika i pretnji navedenih u prethodnoj, dok je uočeno deset novih. U tabeli 1 dat je prikaz izazova, rizika i pretnji iz 2002. godine i ponavljanje dela istih u Strategiji iz 2017. godine.

Tabela 1 - Izazovi, rizici i pretnje u SNB Republike Hrvatske iz 2002. i 2017. godine

\begin{tabular}{|l|c|c|}
\hline \multicolumn{1}{|c|}{ Izazovi, Rizici, Pretnje } & SNB 2002 & SNB 2017 \\
\hline Opasnost od vojne pretnje & $\mathbf{+}$ & $\mathbf{+}$ \\
\hline Transnacionalne pretnje & $\mathbf{+}$ & \\
\hline Sukobi na tranzitnim pravcima i oko resursa & $\mathbf{+}$ & \\
\hline Tranzicijski problemi država istočne i j/i Evrope & $\mathbf{+}$ & $\mathbf{+}$ \\
\hline $\begin{array}{l}\text { Tranzicija Hrvatske (korupcija, ekonomija, negativna } \\
\text { demografska kretanja, visoka stopa nezaposlenosti) }\end{array}$ & $\mathbf{+}$ & $\mathbf{+}$ \\
\hline Problemi u funkcionisanju pravosuđa & $\mathbf{+}$ & $\mathbf{+}$ \\
\hline Negativna demografska kretanja & $\mathbf{+}$ & $\mathbf{+}$ \\
\hline Prava i zaštita nacionalnih manjina & $\mathbf{+}$ & $\mathbf{+}$ \\
\hline Granična pitanja sa pojedinim susedima & $\mathbf{+}$ & \\
\hline $\begin{array}{l}\text { Globalni terorizam, organizovani kriminal, korupcija, } \\
\text { krijumčarenje oružja, droge, ilegalne migracije }\end{array}$ & $\mathbf{+}$ & \\
\hline Prirodne, tehničke i tehnološke nesreće & $\mathbf{+}$ & \\
\hline Sirenje infektivnih bolesti i zaraza & $\mathbf{+}$ & \\
\hline Posledice petogodišnjeg rata & $\mathbf{+}$ & \\
\hline Kompjuterski kriminal i ugrožavanje informatičkih sistema & $\mathbf{+}$ & \\
\hline Negativne posledice globalizacije & $\mathbf{+}$ & \\
\hline
\end{tabular}

\footnotetext{
${ }^{25}$ Isto, str. 1.

${ }^{26}$ Strategija NB Republike Hrvatske, Zagreb, 2002, str. 2.

${ }^{27}$ Isto, str. 4.
} 
Zaključuje se da su izazovi, rizici i pretnje u obe strategije identifikovani na deskriptivni način, pri čemu isti odaje izvesnu dozu nesistematičnosti i nepovezanog nabrajanja. Vršeći njihovo međusobno poređenje, bitno je naglasiti da, uz manje razlike, sagledavanje izazova, rizika i pretnji nije bitnije izmenjeno u najvišim strateškim dokumentima $\mathrm{Hr}$ vatske. Strukturno gledajući, oblasti koje se bave vrednostima, interesima i ciljevima, u navedenim strategijama su različito razrađene, sa uočenim kompozicijskim "napretkom“. Naime, u Strategiji iz 2017. godine na osnovu temeljnih vrednosti države, određenih njenim Ustavom, definisani su nacionalni interesi, sa čijim kontekstom su povezani njeni strateški ciljevi, a njihovo dostizanje opisano kroz različite instrumente i mehanizme, što predstavlja najobimniji deo samog teksta Strategije. ${ }^{28}$ Da bi se shvatila suština sadržaja Strategije nacionalne bezbednosti Republike Hrvatske iz 2017. godine, neophodno je analitički sagledati njene delove i pokušati uočiti njene glavne poruke.

Polazeći od uvodnog dela, uočava se pokušaj originalnog pristupa izrade najvažnijeg strategijsko-doktrinarnog dokumenta jedne države, obzirom da su jedino u hrvatskoj strategiji, pored samog uvoda, dodatno izneti vizija i bezbednosni koncept. U ovom delu Strategije sasvim jasno je ukazano na ubeđenost u stanovište da je Hrvatska vodila tzv. „Domovinski rat“, kao odbrambeni rat za oslobođenje državne teritorije, pri čemu je izvršeno povezivanje iskustava iz tog rata sa željenim ostvarenjem bezbednosnih ciljeva. Isto tako važno je i naglašavanje članstva u NATO i EU, kojim je ostvarila svoje veoma važne spoljnopolitičke i bezbednosne ciljeve. $^{29}$ Zanimljivo je da se kroz viziju, kao sveobuhvatno i koordinirano delovanje, posebno ističe nastojanje za trajnom brigom o pripadnicima hrvatskog naroda u drugim državama. Konceptualno, određivanjem politike i instrumenata za ostvarivanje vizije i nacionalnih interesa žele se postići bezbednosni uslovi koji će omogućiti uravnotežen i kontinuiran razvoj države i društva. ${ }^{30}$

Bezbednosno okruženje analizirano je u tri dimenzije. Tako su na globalnom nivou, pored relativno „starih“ izazova, klimatskih promena, demografskih kretanja, migracija stanovništva, razvoja novih tehnologija i globalizacije ekonomije, naglašeni i novi rizici. Tu se pre svega misli na geopolitička nadmetanja velikih sila, mogućnosti zloupotreba informacionih i komunikacijskih tehnologija za napade u kibernetičkom (sajber) prostoru i nekontrolisan porast potreba sve većeg broja država za hranom, vodom, energijom i komunikacijama. ${ }^{31}$

Na nivou Evrope i evropskog susedstva zaključeno je da EU okružuje pojas nestabilnosti koji se prostire od severne Afrike, preko Bliskog istoka do Kavkaza i srednje Azije, pri čemu je nedvosmisleno ukazano da se upravo Hrvatska nalazi na spoljašnjim granicama ove organizacije. Uz terorizam kao stalnu pretnju, navedene su masovne migracije, demografski deficit u razvijenim državama i zavisnost od energenata, uz malu verovatnoću velikog konvencionalnog sukoba sa učešćem NATO i EU ali naglašenu osetljivost pojedinih regiona „usled geopolitičkih nadmetanja i preklapanja interesa velikih sila“, zbog čega se mogu javiti različiti hibridni oblici pretnji. ${ }^{32}$

Hrvatska je stanje u svom jugoistočnom okruženju definisala kao „izvor potencijalnih izazova“, gde „politička nestabilnost, nedovoljno izgrađene državne institucije, korupcija, visoka stopa nezaposlenosti, kao i socijalne, etničke i međunacionalne napetosti“ neposredno utiču

\footnotetext{
${ }^{28}$ Strategija NB Republike Hrvatske, Zagreb, 2017, str. 6.

${ }^{29}$ Strategija NB Republike Hrvatske, Zagreb, 2017, str. 1.

${ }^{30}$ Isto.

${ }^{31}$ Isto, str. 3.

32 Isto.
} 
na hrvatske interese. Donosioci ove Strategije smatraju da je u neposrednom državnom okruženju (Bosna i Hercegovina, Srbija, prim. aut), osim NATO i EU, otvoren uticaj drugih globalnih i regionalnih aktera, uz različite spoljnopolitičke ciljeve i aspiracije. Nedvosmisleno je ukazano na snažan islamski radikalizam, radikalni nacionalizam utemeljen na velikodržavnim ideologijama, što uz „difamacijsku kampanju“ direktno narušava verodostojnost Republike Hrvatske. ${ }^{33}$ Pored ranije prepoznatih kriminalnih ruta koje vode preko hrvatske zemlje, pretnja bezbednosti postoji i od proliferacije oružja za masovno uništavanje, organizovanog kriminala i izrazito frekventnih migracija. Sa druge strane, u istom tom okruženju, Hrvatska vidi priliku za širenje političke, privredne, trgovinske, energetske i druge saradnje, uz izgradnju politike poverenja i dijaloga. ${ }^{34} \mathrm{Na}$ osnovu stavova koji se odnose na jugoistočno susedstvo, ne može se poreći utisak da ova Strategija vešto maskira stvaran, i u praksi primenjen, pristup Republike Hrvatske prema sopstvenom okruženju, posebno susednim državama.

Izradom nove strategije nacionalne bezbednosti, njeni tvorci identifikovali su političko i obaveštajno delovanje prema Hrvatskoj od strane država koje su sukobljene sa NATO i EU, hibridno delovanje, ekstremizam pojedinaca i grupa unutar države, kibernetičke (sajber) pretnje, nepovoljne globalne ekonomske trendovi, osetjivost na poplave i prirodne nesreće i porast siromaštva, energetsku zavisnost, klimatske promene, narušavanje okoline i zaostala minsko-eksplozivna sredstva, kao izazove, rizike i pretnje koje su promenile bezbednosne okolnosti u odnosu na 2002. godinu, kada je donošena prethodna Strategija. Nerešena pitanja razgraničenja sa pojedinim susednim državama takođe je prepoznato kao izazov koji država nije uspela da otkloni u prethodnom periodu. Preostali izazovi, rizici i pretnje, kao što su terorizam, korupcija, organizovani kriminal, nepovoljna demografska struktura, prirodne i ljudskim delovanjem izazvane nesreće, mogu se svrstati u grupu dugoročnih i teže savladivih, zbog čega su i pojmovno zadržani prilikom izrade nove Strategije 2017. godine.

Pozivajući se na najviše vrednosti utvrđenih Ustavom, Hrvatska je definisala četiri nacionalna interesa - „bezbednost stanovništva, teritorijalni integritet i suverenitet RH, dobrobit i prosperitet građana, nacionalni identitet, međunarodni ugled i uticaj RH i položaj Hrvata u Bosni i Hercegovini, u drugim državama i u iseljeništvu“. ${ }^{35}$

Prvi navedeni nacionalni interes, bezbednost stanovništva, teritorijalni integritet $i$ suverenitet Republike Hrvatske operacionalizovan je kroz tri strateška cilja:

1) Dostizanje najvišeg stepena bezbednosti i zaštite stanovništva, kao i kritičnih infrastruktura: smatra se da se ovaj cilj može ispuniti kroz javnu bezbednost, rad policije, funkcionisanje bezbednosno-obaveštajnog sistema i nadzora nad njime, obrazovanje i obuku za poslove javne bezbednosti i efikasno funkcionisanje korporativne bezbednosti. Ovaj cilj podrazumeva i suprotstavljanje terorizmu, integralno upravljanje državnom granicom i ispunjavanje uslova kako bi Hrvatska ušla u Sengenski sporazum. Država se mora efikasno suprotstavljati organizovanom kriminalu, preventivno delovati i suzbijati radikalizam i ekstremizam. Sa druge strane, moraju se unaprediti mere za unapređenje zaštite i spasavanja i unapređenje civilne zaštite, uz nastavak uklanjanja minskih opasnosti. Poseban izazov jesu i mere za smanjenje rizika od prirodnih katastrofa; ${ }^{36}$

\footnotetext{
${ }^{33}$ Strategija NB Republike Hrvatske, Zagreb, 2017, str. 3.

${ }^{34}$ Isto, str. 4.

${ }^{35}$ Isto, str. 2.

${ }^{36}$ Strategija NB Republike Hrvatske, Zagreb, 2017, str. 6.
} 
2) uspostavljanje i razvoj sistema državne bezbednosti: ovaj sistem će činiti glavna tela nadležna za odbranu, unutrašnje poslove, spoljne poslove, civilnu zaštitu, finansije i pravosuđe, organi bezbednosno-obavešajnog sistema i javne i privatne organizacije i drugi. Glavno telo sistema predstavlja Veće za nacionalnu bezbednost. Sistem državne bezbednosti će se oslanjati i učestvovati u NATO i EU operacijama upravljanja krizama. ${ }^{37}$

3) razvoj i održavanje snažne i aktivne odbrane: Hrvatska, kao punopravna članica NATO je sve aktivnosti podredila kolektivnoj odbrani, pri čemu je pored odbrane teritorijalne celovitosti, suvereniteta i nezavisnosti, orijentisana i ka odbrani saveznika, doprinosu međunarodnoj bezbednosti i podršci civilnim institucijama. Značajnu funkciju obavlja kontrolom na moru i morskom plovidbom, u saradnji sa telima NATO i EU. Planiran je i razvoj posebnih sposobnosti i snaga za potrebe kolektivne odbrane NATO, kako bi doprinosila misijama i operacijama Zajedničke bezbednosne i odbrambene politike EU, što će biti komplementarno sa razvojem odbrambenih sposobnosti u okviru NATO. ${ }^{38}$

Ostvarenje Dobrobiti i prosperiteta građana, kao drugog nacionalnog interesa, planirano je kroz tri strateška cilja:

4) ekološka Hrvatska i razvoj snažne i održive ekonomije: Ova država nastoji da nizom mera kvalitativno promeni odnos prema svojim prirodnim bogatstvima. Očekivan je napredak regionalnog razvoja koji će se odraziti na ekonomski i opšti društveni razvoj. I u ovoj oblasti oslonac se traži u korišćenju ekonomskih segmenata NATO i EU, uz poklanjanje pažnje tehnološkom usavršavanju i smanjenju energetske zavisnosti. ${ }^{39}$

5) demografska obnova i revitalizacija hrvatskog društva: Uočen je trend depopulacije delova teritorije i neravnomernog regionalnog razvoja, što se želi ublažiti preduzimanjem niza mera. Nastoji se sprovoditi pronatalitetna politika, unapređenje sistema socijalnih i materijalnih prava, zdravstvene zaštite i socijalne sigurnosti. ${ }^{40}$

6) razvoj državne uprave po meri građana i strateške komunikacije: Uočena je potreba prilagođavanja pravosudnog sistema novim pojavnim oblicima ugrožavanja zakona, jačanja institucionalne sposobnosti i saradnje nadležnih regulatornih organizacija i organa javne uprave, uz neophodnu modernizaciju upravnih usluga i funkcija. Pored toga, planirano je razvoj informacijskih i komunikacionih sistema u kibernetičkom prostoru. Kao i u drugim zemljama, postoji potreba za temeljnim promenama u sistemu vaspitanja i obrazovanja, sa posebnom brigom u prirodnim, tehničkim i interdisciplinarnim područjima, za koja se smatra da su bila zanemarena. ${ }^{41}$

Unapređenje nacionalnog identiteta, međunarodnog ugleda i uticaja Republike Hrvatske, obezbediće se ukoliko se realizuju sledeći ciljevi:

7) zaštita, jačanje i promocija najviših vrednosti ustavnog poretka i hrvatskog nacionalnog identiteta: posebnu brigu država će imati na očuvanju hrvatskog jezika, koji se doživljava kao najvažnije obeležje nacionalnog identiteta. lako se deklarativno zalaže za poštovanje i ostvarivanje nacionalnih prava i prava nacionalnih manjina, pristup u kom se navodi „promovisanje naučno utemeljene istine o domovinskom ratu“, „suprotstavljanje pokušajima difamacije hr-

\footnotetext{
${ }^{37}$ Isto, str. 8.

${ }^{38}$ Isto, str. 10

${ }^{39}$ Strategija NB Republike Hrvatske, Zagreb, 2017, str. 11.

${ }^{40}$ Isto, str. 14

${ }^{41}$ Isto.
} 
vatskog naroda i države“, uz već preduzete mere, svakako ukazuje da ova zemlja ne pokazuje potrebne kapacitete za sopstveno preispitivanje po pomenutoj tematici. ${ }^{42}$

8) jačanje međunarodnog ugleda i uticaja: Hrvatska doprinosi delovanju multinacionalnih organizacija i integracija čiji je punopravan član, posebno UN, NATO, EU, OEBS i Saveta Evrope. Svojim odnosom i delovanjem pokazuje se predanost vrednostima EU, dok se istovremeno NATO gleda kao garant mira, stabilnosti i bezbednosti, dok se sa druge strane, kroz evroatlantske integracije, jača vlastita pozicija u međunarodnim odnosima. Obzirom na svoju energetsku zavisnost, Hrvatska vidi svoje mesto i ulogu u širenju broja solucija za vlastito snabdevanje naftom i gasom, u rešavanju otvorenih pitanja razgraničenja, dok se posebna pažnja (deklarativno) priklanja očuvanju manjinskih grupa i njihovih prava. Jugoistočni susedi imaju strategijski značaj, a biće data podrška zemljama j/i Evrope da postanu članice NATO i EU. ${ }^{43}$

Svakako ne manje važan, nacionalni interes, koncipiran kao Hrvati izvan Republike Hrvatske, planiran je da se ostvari kroz jedan strateški cilj - osiguranje opstanka, zaštita identiteta i političkog subjektiviteta hrvatskog naroda, kao konstitutivnog u $\mathrm{BiH}$, zaštita i podrška Hrvatima u drugim državama i dijaspori. Osnove dostizanja tog cilja u strategiji 2017 predstavljaju stanovišta da delovi hrvatskog naroda vekovima žive u drugim državama srednje i j/i Evrope, dok su Hrvati u BiH domicilni, konstitutivni i ustavnopravni i konstitutivni narod $\mathrm{BiH}$. Republika Hrvatska vrlo eksplicitno u svojoj Strategiji navodi da će odlučno ispunjavati svoju ustavnu obavezu o posebnoj brizi za hrvatski narod u $\mathrm{BiH}$, uz sopstveno zalaganje za brže evroatlanske integracije i druge projekte ove zemlje. Navedeno je da položaj i opstanak Hrvata, kao nacionalne manjine u drugim državama srednje i j/i Evrope, zavisi od stepena razvoja političkog sistema i demokratskih institucija u tim državama.

Usvajanjem ovog dokumenta svaka država, pa i Hrvatska, svrstava se u red zemalja koje ozbiljno, studiozno i planski razmatraju pitanja od najvišeg nacionalnog značaja Nakon proučavanja samog teksta, a uzimajući u obzir zvanične nastupe pripadnika najviših nivoa vlasti, može se reći da strategiju nacionalne bezbednosti ne čini samo ono što u zvaničnom tekstu stoji, već da je mnogo onoga što se u dokumentu ne napiše, ali se i te kako sprovodi u praksi. Nesporno je da je Hrvatska ostvarila ključne nacionalne interese i ciljeve ulaskom u NATO i EU, ali u istom tom dokumentu nisu jasno utvrđeni spoljnopolitički i bezbednosni ciljevi, već samo nacionalni. Kad je bezbednost u pitanju, iz dokumenta se gotovo nedvosmisleno može zaključiti da je članstvo u NATO bio i ostao „interes nad interesima“ i cilj Hrvatske. Pod kišobranom NATO i delimičnim osloncem na članstvo u EU, Hrvatska je svojom strategijom nacionalne bezbednosti pokušala da se prikaže kao zaštitnik ljudskih prava, zbog čega je formalno njena suština i fokus - ljudska, a ne nacionalna bezbednost. Nasuprot teoriji, u praktičnom postupanju Hrvatska zasigurno predstavlja jedan od generatora nebezbednosti i nestabilnosti u regionu, unazad nekoliko godina. Čini se neshvatljivim da se u državi koja zastupa najviše evropske vrednosti, ljudska prava nacionalnih manjina nipodaštavaju, ne suzbija neofašizam i ultradesničarske snage, veličaju ratni zločinci i čine mnogi drugi postupci koji govore u prilog ovoj činjenici.

\footnotetext{
42 Isto, str. 16.

${ }^{43}$ Strategija NB Republike Hrvatske, Zagreb, 2017, str. 17

${ }^{44}$ Isto, str. 19.
} 


\section{Sličnosti i razlike strategija nacionalne bezbednosti Republike Srbije i Republike Hrvatske}

Obe zemlje su strukturu svog osnovnog dokumenta iz oblasti nacionalne bezbednosti definisale na sličan način, uz određene specifičnosti. Ovim dokumentom obuhvaćeno je bezbednosno okruženje, identifikovani izazovi, rizici i pretnje bezbednosti i promovisani nacionalni interesi i ciljevi, a redosled navođenja konkretnih sadržaja zavisi od primenjene metodologije izrade. $U$ narednom delu, komparativna analiza strategija nacionalne bezbednosti Republike Srbije i Republike Hrvatske podrazumeva analizu njihovih strukturnih elemenata, odnosno naglašavanja specifičnosti, sličnosti i razlika u načinu doživljavanja vlastitog bezbednosnog okruženja, identifikaciji bezbednosnih izazova, rizika i pretnji i definisanja nacionalnih vrednosti, interesa i ciljeva.

Već pri samom sagledavanju i proceni vlastitog bezbednosnog okruženja uočava se glavna, moglo bi se reći i presudna, razlika između ova dva dokumenta. Obe zemlje prepoznale su posledice razlika u stepenu ekonomskog i kulturnog razvoja različitih regiona sveta što dovodi do porasta siromaštva i socijalne ugroženosti stanovništva i čini pogodno tlo za nastanak i razvoj negativnih demografskih i psihosocijalnih pojava. Prisutni su regionalni i lokalni sukobi, ekstremizam i terorizam, organizovani kriminal, proliferacija oružja za masovno uništenje, ilegalne migracije i klimatske promene i sve izraženiji deficit energetskih resursa. Interesantno je da Hrvatska na globalnom nivou ne pridaje značaj mogućnosti izbijanja vojnih sukoba, ali konstatuje geopolitička nadmetanja velikih sila. ${ }^{45}$ lako postoji velika sličnost kada je procena mogućeg ugrožavanja bezbednosti na globalnom nivou u pitanju, ove dve države imaju različita uporišta. Sa jedne strane je Republika Srbija, koja je proglasila svoju vojnu neutralnost i koja vidi „Zajedničku spoljnu i bezbednosnu politiku EU i uključivanje evropskih odbrambenih snaga u rešavanje bezbednosnih problema“" ${ }^{46}$ Nasuprot njoj, Republika Hrvatska je ostvarila svoj ranije određeni spoljnopolitički i bezbednosni cilj, članstvo u NATO i EU, pa na iste probleme gleda kroz "kišobran kolektivne bezbednosti", sa sigurnošću koju on sa sobom nosi.

Pristup proceni regionalnog okruženja u znatnoj meri je različit u predmetnim strategijama. Za Hrvatsku su Evropa i evropsko susedstvo regionalni nivo, pa je i procena mogućih oblika ugrožavanja bezbednosti sagledana iz tog „zajedničkog“ ugla. Prepoznata je specifičnost geografskog položaja ove države u kontekstu granica EU, uticaja drugih faktora i činilaca, gde su posebno istaknuti terorizam, migracijska kretanja, ali i geopolitičke napetosti uz preklapanje interesa velikih sila. Republika Srbija je svoje regionalno okruženje analizirala iz dosta drugačije perspektive. lako je konstatovano da su sve zemlje opredeljene za ulazak u EU, a većina i u NATO ${ }^{47}$ u Strategiji su navedene brojne pojave koje negativno utiču na bezbednosnu situaciju i međusobne odnose. Indikativno je da se gotovo svi oblici ugrožavanja direktno odnose ili utiču na prostor Srbije, gde posebnu težinu imaju oni kojima se najdirektnije ugrožava suverenitet i teritorijalni integritet, odnosno prava građana. Priroda ovih problema je dosta složena, zbog čega države regiona sve više nastoje da in zajedničkim naporima rešavaju i da suzbijaju negativne procese koji ugrožavaju njihovu nacionalnu, ali i regionalnu bezbednost.

\footnotetext{
${ }^{45}$ Strategija NB Republike Hrvatske, Zagreb, 2017, str. 2.

${ }^{46}$ Strategija NB Republike Srbije, 2009, str. 5.

${ }^{47}$ Od donošenja Strategije NB Republike Srbije do danas, sve zemlje u okruženju, osim Republike Severne Makedonije i Bosne i Hercegovine, su postale članice NATO pakta.
} 
U Strategiji nacionalne bezbednosti Republike Srbije kao poseban aspekt bezbednosnog okruženja razmatrani su problemi koji egzistiraju na njenoj teritoriji, gde je kao osnovna pretnja naveden pokušaj otcepljenja teritorije AP Kosovo i Metohija. Značaj je dat i posledicama višegodišnjeg građanskog rata, međunarodne izolacije, NATO agresije i izraženim problemima tranzicije, koji su relativno sažeto obuhvaćeni. ${ }^{48}$ Republika Hrvatska je svojom strategijom nacionalne bezbednosti iz 2017. godine značajno promenila pristup razmatranjima ugrožavanja bezbednosti na lokalnom nivou. Činjenica da je ovaj deo poglavlja bezbednosnog okruženja nazvan Jugoistočno susedstvo, jasno ukazuje da se u tom kontekstu, Republika Srbija i Republika Bosna i Hercegovina, posredno i neposredno, vide kao izvori pretnji bezbednosti ove zemlje.

Posebno je važno istaći da su Hrvatska i Srbija na sličan način definisale bezbednosne izazove, rizike i pretnje. Od 16 posebnih oblika ugrožavanja bezbednosti u hrvatskoj Strategiji nacionalne bezbednosti, čak 14 se nalazi i u najvažnijem dokumentu Republike Srbije u oblasti bezbednosti, što je prikazano u tabeli 2, dok se preostali izazovi, rizici i pretnje u većoj meri odnose na specifičnosti samih zemalja.

Tabela 2 - Pregled izazova, rizika i pretnji u Strategijama NB R Hrvatske i R Srbije ${ }^{49}$

\begin{tabular}{|c|c|c|}
\hline IZAZOVI, RIZICI I PRETNjE & 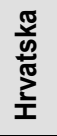 & $\frac{\pi}{\frac{\pi}{2}}$ \\
\hline opasnost od vojne pretnje & + & + \\
\hline nerešena pitanja razgraničenja s pojedinim susednim državama & + & + \\
\hline političko i obaveštajno delovanje prema državi & + & + \\
\hline hibridno delovanje & + & \\
\hline međunarodni terorizam & + & + \\
\hline ekstremizam & + & + \\
\hline korupcija & + & + \\
\hline organizovani kriminal & + & + \\
\hline kibernetičke (sajber) pretnje & + & + \\
\hline globalizacija & + & + \\
\hline nepovoljna demografska struktura & + & + \\
\hline energetska zavisnost & + & + \\
\hline klimatske promene & + & + \\
\hline narušavanje okoline & + & + \\
\hline zaostala minsko-eksplozivna sredstva & + & \\
\hline prirodne i ljudskim delovanjem izazvane nesreće & + & + \\
\hline separatističke težnje & & + \\
\hline protivpravno jednostrano proglašenje nezavisnosti KiM & & + \\
\hline oružana pobuna & & + \\
\hline proliferacija OMU & & + \\
\hline nerešen status i težak položaj izbeglih lica & & + \\
\hline pojava i širenje infektivnih bolesti i zaraze & & + \\
\hline narkomanija & & + \\
\hline delovanje verskih sekti i kultova & & + \\
\hline
\end{tabular}

\footnotetext{
${ }^{48}$ Strategija NB Republike Srbije, 2009, str. 7.

${ }^{49}$ izvor: autor.
} 
U svojim Ustavima i Strategijama nacionalne bezbednosti, obe države su se prilikom definisanja nacionalnih interesa pozivale na nacionalne vrednosti, koje su opšteprihvaćene vrednosti zasnovane na Evropskoj istoriji, kulturi i tradiciji, pri čemu ih Republika Hrvatska u svom dokumentu nije eksplicitno i navela. Sa druge strane, osnovnim nacionalnim vrednostima u Srbiji se smatraju nezavisnost, suverenitet, teritorijalni integritet, sloboda, jednakost, izgradnja i očuvanje mira, vladavina prava, demokratija, socijalna pravda, ljudska prava i slobode, nacionalna, rasna, verska ravnopravnost i ravnopravnost polova, nepovredivost imovine i očuvanje životne sredine. ${ }^{50}$ Nacionalne vrednosti se štite ostvarivanjem nacionalnih interesa, čija zaštita je zapravo smisao postojanja politike nacionalne bezbednosti i sistema nacionalne bezbednosti.

Različit je i način određivanja i sadržaj nacionalnih interesa u oblasti bezbednosti. Dok se u Strategiji nacionalne bezbednosti Republike Srbije navode i ponaosob objašnjavaju, u istorodnom dokumentu hrvatske države nacionalni interesi su jednostavno taksativno ispisani. Nacionalni interesi obuhvataju sve oblasti društvenog života i u skladu su sa demokratskim tekovinama i standardima savremenog društva. Takođe, od sedam definisanih nacionalnih interesa Republike Srbije, pet se odnosi na državu u celini, dok se preostala dva odnose neposredno na njene građane, odnosno na veze sa Srbima koji žive i rade u inostranstvu. Veoma je interesantno da se u Strategiji nacionalne bezbednosti Republike Srbije ni jednom rečju ne pominje vojna neutralnost, pa se i u preambuli iskazuje spremnost „Republike Srbije da u okviru Organizacije ujedinjenih nacija, evropskih i drugih međunarodnih organizacija i regionalnih struktura, doprinosi izgradnji i unapređenju sopstvene, regionalne i globalne bezbednosti“ ${ }^{51}$

Sa druge strane, Republika Hrvatska je u svojoj strategiji odredila četiri nacionalna interesa, od kojih se dva odnose na nivo države, a druga dva usmerena su ka dobrobiti građana i položaju Hrvata u drugim državama. Time Hrvatska, barem deklarativno, "brani" svoju želju da bezbednost temelji na modelu ljudske bezbednosti, odnosno bezbednosti pojedinca. ${ }^{52}$ Takođe, u istom dokumentu može se uočiti i jedna metodološka novina, obzirom da je na osnovu nacionalnih interesa, definisano devet strateških ciljeva, čiji način ostvarivanja je objašnjen kroz različite instrumente i mehanizme. Vredno pažnje je svakako i jasno zalaganje hrvatske države za pripadnike hrvatskog naroda u Bosni i Hercegovini, kao konstitutivnog u ovoj državi, pri čemu za hrvatsku državu ovaj cilj predstavlja ustavnu obavezu. ${ }^{53}$ Izvršenom analizom dolazi se do zaključka da se i u oblasti ostvarivanja strateških ciljeva, koncept Hrvatske zasniva na benefitima koje donosi članstvo u NATO i EU, kao i držanju svojevrsnog "istorijskog" časa, kada je region u pitanju.

\section{Zaključak}

Poput svih zemalja Jugoistočne Evrope, Republika Srbija i republika Hrvatska su se krajem prošlog i početkom novog veka našla u okolnostima koje su zahtevale sopstveno određenje po najvažnijim sadržajima svoje nacionalne bezbednosti. Sa definisanjem svo-

\footnotetext{
${ }^{50}$ Strategija NB Republike Srbije, Beograd, 2009, str. 13.

${ }^{51}$ Isto, str. 2.

${ }^{52}$ Strategija NB Republike Hrvatske, Zagreb, 2017, str. 1.

${ }^{53}$ Isto. Str. 19.
} 
jih najviših vrednosti i nacionalnih interesa, uz aktivno sprovođenje vlastitih politika nacionalne bezbednosti, obe države radile su na ostvarivanju svojih usvojenih ciljeva.

Razvoj događaja, društvenih prilika i okolnosti na ovim prostorima istim tim državama u izvesnoj meri je uticao na uspešnost u vođenju bezbednosnih politika i očuvanje nacionalnih interesa. Razvoj društvenog života i tehnologije, zajedno sa svojim pozitivnim stranama i progresom, iznedrio je i čitav niz problema širom sveta, kojima je zajedničko da su asimetrični, netradicionalni i transnacionalni, zbog čega ni jedna zemlja na svetu nije izostavljena kao potencijalna „meta“. Dugi niz godina unazad, region je i dalje opterećen brojnim nerešenim pitanjima i sukobima interesa, sa značajnim razlikama u sopstvenim pozicijama, koje sa sobom nosi članstvo u Evropskoj uniji i NATO.

Republika Srbija, suočena sa pokušajem protivpravnog prekrajanja vlastite teritorije uz blagonaklonost Zapada, sa jedne, i svojim čvrstim opredeljenjem za punopravno članstvo u Evropskoj uniji, ima potrebu da odmereno, ali odlučno, zastupa svoju bezbednosnu politiku. Upravo je Strategija nacionalne bezbednosti uporište te najviše državne politike zasnovane na pravilnoj identifikaciji izazova, rizika i pretnji, nacionalnim vrednostima i njihovoj odbrani kroz nacionalne interese. Posebnu pažnju u razmatranjima sprovođenja strategije nacionalne bezbednosti republike Srbije ima i činjenica da nigde u dokumentu vojna neutralnost nije niti pomenuta, niti pojašnjena, a ima značajnu težinu prilikom određivanja prema zbivanjima u regionu i svetu.

Republika Hrvatska je, nakon ostvarivanja najviših državnih ciljeva - članstva u NATO i EU, donela novu Strategiju nacionalne bezbednosti, po čemu prednjači u regionu, obzirom da su aktivnosti na donošenju takvog dokumenta u drugim državama regiona u povoju. lako je njen sadržaj dorađeni tekst prethodne, značajno mesto i ulogu imaju stavovi koji direktno proizlaze iz članstva u NATO i EU. Međutim, u svakom slučaju treba činiti razdvajanje između stavova utvrđenih novom Strategijom nacionalne bezbednosti Republike Hrvatske i njenog postupanja u praksi. U tom smislu, ova strategija je više populistički pokušaj hrvatske države, nego stvaran iskaz njihovog odnosa prema nacionalnoj bezbednosti, posebno ne prema ljudskoj bezbednosti kao zvanično proklamovanoj karakteristici novog strateškog dokumenta.

\section{Literatura}

[1] М. Ковач, Д. Стојковић, Стратегијско планирање одбране, Београд, 2009.

[2] Стратегија националне безбедности Републике Србије, Београд, 2009.

[3] Стратегија националне безбедности републике Хрватске, Загреб, 2017.

[4] https://www.dalmacijadanas.hr/26-godina-od-priznanja-rh-znate-li-koja-je-zemlja-prvapriznala-hrvatsku nato/

[5] http://www.mvep. hr/hr/vanjska-politika/multilateralni-odnosio/multi-org-inicijative/nato/hrvatska-i-

[6] https://vlada. gov.hr/proslava-pristupanja-hrvatske-u-europsku-uniju/1155 